\title{
Pimentel, Fernando. (2011) O fim da Era do Petróleo e a Mudança do Paradigma Energético Mundial: Perspectivas e Desafios para a Atuação Diplomática Brasileira. Brasília: Fundação Alexandre de Gusmão. ISBN: 978-85-7631-308-3
}

Rev. Bra. Est. Def. v. 2, no 1, jan./jun. 2015, p. 185 - 187

ISSN 2358-3932

\section{GRACIELA DE CONTI PAGLIARI* TIAGO GABRIEL TASCA**}

A obra "O fim da Era do Petróleo e a Mudança do Paradigma Energético Mundial: Perspectivas e Desafios para a Atuação Diplomática Brasileira" (Brasília: Fundação Alexandre de Gusmão, 2011) desenvolve uma narrativa em torno dos desafios, condicionantes e oportunidades à segurança energética brasileira face ao atual cenário do Peak Oil. Fernando Pimentel é diplomata de carreira e possui formação em Economia, pela Universidade de São Paulo, com atuação nas Embaixadas do Brasil em Washington, Nova Déli e Assunção. Já trabalhou no Departamento Econômico e no Gabinete do Ministro de Estado, em Brasília. Pimentel já exerceu função de Secretário-Adjunto de Assuntos Internacionais do Ministério da Fazenda e, atualmente, é Subsecretário de Instituições Econômico-Financeiras e Cooperação Internacional do mesmo Ministério.

Visando a enquadrar a teoria do Peak Oilà atual preocupação energética global, Pimentel dialoga com as arestas histórico-conjunturais do Oriente Médio no tocante à geopolítica energética. $\mathrm{O}$ autor perpassa para o âmbito sul-americano ao destacar as oportunidades brasileiras e seus impactos dentro de dois possíveis cenários de crise. Dentro de uma dialética de energia e política externa brasileira, Pimentel encaixa essa abordagem teórica em um panorama de reconfiguração energética mundial.

A lente teórica do Peak Oil (ou Hubbert's Peak) permite observar que o ritmo de produção de um recurso escasso acelera-se a partir da sua descoberta e, ao passo que os recursos de extração mais fácil ou barata são explorados, atinge-se um ápice na extração que é seguido de declínio que

\footnotetext{
* Doutora em Relações Internacionais (UnB) e professora da graduação e do Programa de Pós-Graduação em Relações Internacionais da Universidade Federal de Santa Catarina. E-mail: graciela.pagliari@ufsc.br.

**Graduando em Relações Internacionais pela Universidade Federal de Santa Catarina. E-mail: tiagotasca@live.com.
} 
tende a zero. Ao lograr esse acme, a extração diária de recursos apresentará caráter declinante, uma vez que esse momento configura-se como o zênite na produção mundial de petróleo. Outrossim, a abordagem de Hubbert estima que as reservas mais fáceis de serem exploradas serão alvo imediato de exploração, havendo um gradual desafio à exploração e extração de novas jazidas petrolíferas.

O livro constitui-se em quatro capítulos que apresentam uma dimensão analítica atrelada a cenários de prospecção de alternativas, lançando mão da segurança nacional em termos energéticos. No primeiro capítulo, o fio condutor é a história. A partir da Primeira Guerra Mundial, a posição de Churchill, a dependência energética japonesa, a nacionalização do Canal de Suez por Nasser (1956), a crise do petróleo (1973), a Guerra Irã-Iraque (1980), a invasão soviética no Afeganistão (1979) e a Doutrina Carter (1980) mostram os reflexos, em linhas gerais, da oil weapon caracterizada por Pimentel em termos geopolíticos e geoestratégicos. A ressonância desses efeitos para o Brasil, sobretudo na década de 1970, desperta a busca pela redução da vulnerabilidade energética brasileira a partir da Usina de Itaipu, do convênio nuclear com a Alemanha e da implementação do PROÁLCOOL. Os primeiros pilares na edificação da segurança energética brasileira são construídos diante dessa dimensão global de crise de recursos.

No capítulo dois, são apresentadas alternativas para as consequências do Peak Oil. Pimentel divide o capítulo em duas seções: as soluções via combustíveis fósseis (xisto e areias betuminosos, carvão e gás natural), e alternativas via energia renovável (energia solar, eólica, nuclear e hidrelétrica, além dos biocombustíveis). Ao se debruçar sobre a competitividade do biocombustível brasileiro como catalisador da diminuição da vulnerabilidade energética do Brasil, o autor trabalha com o hidrogênio, fusão nuclear e carros elétricos como a energia do futuro. Pimentel conclui, já nesse segundo capítulo, que a iminência do Peak Oil será um acelerador de mudanças no sentido de oferecer uma resposta à crise de abastecimento.

Na terceira parte do livro, dois cenários de crise são apresentados: um panorama de pouso forçado, dando-se forçosamente mediante um estopim, como o choque do petróleo de 1973, e outro de transição induzida, de forçada utilização de recursos renováveis e não-renováveis via investimentos em infraestrutura. Pimentel revela o otimismo do segundo cenário. $\mathrm{O}$ capítulo completa-se por uma análise dos impactos econômicos e geopolíticos de cada cenário. Os efeitos econômicos serão sentidos em termos de exportação e importação de energia, além das ascensões chinesa e indiana que, segundo o autor, modificarão o comércio exterior energético. Em se 
tratando dos reflexos geopolíticos, o aumento das fricções no Golfo Pérsico, na Ásia Central e no Norte da África é notável. Já no segundo cenário, a gradual perda de importância do petróleo levará à diminuição deste como oil weapon, colocando novos países no eixo estratégico da energia - inclusive o Brasil, no ramo dos biocombustíveis.

As linhas do capítulo quatro desenham as perspectivas para o Brasil e para a América do Sul diante das alterações internacionais no campo energético. $\mathrm{O}$ autor enfatiza a situação brasileira rumo à diminuição das suas importações de energia e, consequentemente, à consolidação da segurança energética nacional em consonância com as diretrizes do Plano Nacional de Energia 2030. Não obstante a matriz energética brasileira ser de caráter renovável, as descobertas da camada do Pré-Sal despertam uma reconstrução da segurança energética nacional com condicionantes internacionais, já que a mesma camada conta com investimentos chineses e indianos, argumenta Pimentel.

O debate do capítulo quatro segue sob o prisma da integração energética regional. Diante disso, não se deve, todavia, negligenciar a importância da busca da eficiência e integração energéticas como sustentáculo para a segurança energética brasileira. A despeito dos esforços, o autor lembra que a integração energética na América do Sul é um caminho; porém, vem sofrendo com os custos políticos, como o revisionismo paraguaio sobre Itaipu. Ademais, a diplomacia energética brasileira, pari passu aos interesses estratégicos no campo da segurança nacional, deve levar em conta os desafios diplomáticos em direção à defesa de energias alternativas, das quais o Brasil possui know-how e com as quais supera o gap estrutural-energético.

À guisa de conclusão, o autor lembra que a deflagração do Peak Oil levará a um processo de transição que não está ileso de disputas militares na consolidação da segurança energética. Cabe ao Brasil investir em energias renováveis e utilizá-las como trunfo em negociações multilaterais, não buscando a irrestrita autossuficiência energética, mas levando em consideração que "[o] aprofundamento de vínculos bilaterais pode contribuir efetivamente para a segurança energética tanto do Brasil quanto de seus vizinhos" (Pimentel, 2011: 207). Demais disso, a escolha pela autarquia energética brasileira poderá implicar externalidades regionais advindas do Peak Oil, das quais Pimentel sugere que o país pode não estar preparado para arcar. 